\title{
Establishment of composite experimental animal model of brain edema after cerebral hemorrhagic
}

\author{
Xiao-Yong Zhao ${ }^{1,2}$, Xiao-Li Zhang ${ }^{2,3}$ \\ ${ }^{1}$ Department of Neurosurgery, Affiliated Huadu Hospital, Southern Medical University (People’s Hospital of Huadu District), Guangzhou, China; \\ ${ }^{2}$ The Third School of Clinical Medicine Southern Medical University, Guangzhou, China; ${ }^{3}$ Department of Obstetrics and Gynecology, Affiliated \\ Huadu Hospital, Southern Medical University (People's Hospital of Huadu District), Guangzhou, China \\ Contributions: (I) Conception and design: XL Zhang; (II) Administrative support: XL Zhang; (III) Provision of study materials or patients: XY Zhao; \\ (IV) Collection and assembly of data: XY Zhao; (V) Data analysis and interpretation: XY Zhao; (VI) Manuscript writing: All authors; (VII) Final \\ approval of manuscript: All authors. \\ Correspondence to: Prof. Xiao-Li Zhang. Department of Gynaecology and Obstetrics, Affiliated Huadu Hospital, Southern Medical University (People's \\ Hospital of Huadu District), 48 Xinhua Road, Huadu District, Guangzhou 510800, China. Email: ogzhxl@163.com.
}

Background: The aim of our study was to explore the establishment of an animal model of compound cerebral edema and assist the study of brain edema.

Methods: Sprague Dawley (SD) rats were randomly divided into 6 groups: Group A (IV collagenase + heparin autologous blood + non-heparin autologous blood), Group B (heparin autologous blood), Group C (IV collagenase), Group D (non-heparin autologous blood), Group E (control), Group F (sham); groups A, B, $\mathrm{C}$, and D were modeled, group $\mathrm{E}$ received no treatment, and group $\mathrm{F}$ was injected with normal saline. The Longa/Bederson scales were used to test limb symmetry and score neurological deficits. The composition of brain tissue were measured by potassium $\left(\mathrm{K}^{+}\right)$, sodium $\left(\mathrm{Na}^{+}\right)$, and calcium $\left(\mathrm{Ca}^{2+}\right)$. The glial cells were also subjected to primary culture and identification. The flow cytometry technique (FCM) and terminal uridine nick-end labeling (TUNEL) test were used to detect for the apoptosis of glial cells. Cell counting Kit-8 (CCK-8) and 5-ethynyl-2'-deoxyuridine (EdU) assays were used to observe the proliferation of glial cells; quantitative real-time polymerase chain reaction (qPCR) and western blot measured glial cell matrix metalloproteinase 9 (MMP-9) hole channel protein 4 messenger (m)RNA, and protein expression. The scratch and transwell tests were used to study the glial cell migration and invasion.

Results: Among all groups, according to the results of the Longa/Bederson scores of neurologic impairment, brain tissue water content, and electrolyte $\mathrm{K}^{+}, \mathrm{Na}^{+}, \mathrm{Ca}^{2+}$, group A showed the most significance $(\mathrm{P}<0.05)$. Group A showed the highest rate of apoptosis $(32.27 \pm 3.33)$, least proliferation $(5.33 \pm 1.14)$, and migration and invasion ability were the weakest $(85.35 \pm 8.11 ; 8.08 \pm 1.96)$. The mRNA $(9.31 \pm 0.84 ; 15.69 \pm 1.77)$ and protein $(4.25 \pm 0.27 ; 4.34 \pm 0.33)$ of MMP-9 and aquaporin-4 (AQP4) were the most significant in group A $(\mathrm{P}<0.05)$. Inter-group comparison of groups $\mathrm{B}, \mathrm{C}$, and $\mathrm{D}$ and between groups $\mathrm{E}$ and $\mathrm{F}$ yielded no significant differences $(\mathrm{P}>0.05)$.

Conclusions: By using the obvious signs of brain edema, we were able to establish a composite experimental animal model for the study of brain edema after cerebral hemorrhage, to provide a reliable experimental basis for the study of brain edema.

Keywordsı Composite; cerebral hemorrhage; brain edema; experiment; animal model; establishment

Submitted Oct 23, 2020. Accepted for publication Dec 26, 2020.

doi: 10.21037/apm-20-2308

View this article at: http://dx.doi.org/10.21037/apm-20-2308 


\section{Introduction}

Cerebral hemorrhage has become a disease with high morbidity, disability and mortality. About $35 \%$ of all cerebrovascular diseases, $40 \%$ of survivors left with severe disabilities (1). The pathophysiological changes of intracerebral hemorrhage involve the space-occupying damage of hematoma, the toxic damage of blood components and its lysates, and the activation of immune system (2). Brain edema is an important factor of secondary nerve damage after intracerebral hemorrhage and a key factor of disease change $(3,4)$. Brain edema formation is a very complex pathological process, the exact mechanism is still not very clear (5). The formation of brain edema is considered to be the result of the comprehensive action of various factors $(6,7)$. Cerebral hemorrhage is a common clinical vascular disease, with ever increasing rates of morbidity, mortality, and disability (8). The most important pathological change after cerebral hemorrhage is secondary damage caused by the hematoma itself, and edema the surrounding brain (9). Therefore, prevention and treatment of cerebral edema is the key to reducing the mortality and disability rate of cerebral hemorrhage patients (10). At present, the reproducibility and stability of the animal model of cerebral edema do not meet the required standards for the study of cerebral edema (11).

This study combined a variety of methods to establish an animal model of compound brain edema, and MMP-9 and AQP4 were used to verify the clear signs of brain edema $(12,13)$. With a view to translate the experimental results into the clinical setting, it is of great significance for the diagnosis and treatment of cerebral hemorrhagic brain edema.

We present the following article in accordance with the ARRIVE reporting checklist (available at http://dx.doi. org/10.21037/apm-20-2308).

\section{Methods}

\section{Antibodies and reagents}

Anti-MMP-9 (1:1,000, Santa Cruz Biotech-nology, Santa Cruz, CA, USA, sc-10222), MMP-9 (1:1,000, Cell Signalling Technology, Danvers, MA, USA, Cat\#12640), Anti- AQP4 (1:1,000, Cell Signal-ling Technology, Danvers, MA, USA, Cat\#9559), AQP4 (1:1,000, Santa Cruz Biotechnology, Santa Cruz, CA, USA, sc-44174), antiActin (1:5,000, Santa Cruz Biotechnology, Santa Cruz, CA, USA, sc-47778), GAPDH (1:2,000, Abcam, Cambridge, MA, USA, Cat\#ab8245). Foetal bovine serum (FBS;
GIBCO, Rockville, MD, USA). Annexin V/7AAD apoptosis detection kit AnnexinV (BD, Franklin Lakes, NJ, USA).

\section{Grouping}

A total of 180 specific-pathogen-free (SPF) grade, male, 12 weeks old, Sprague Dawley (SD) rats, weighing 250-300 g were randomly divided into 6 groups $(n=30)$ : Group A (IV collagenase + heparin autologous blood + nonheparin autologous blood), Group B (heparin autologous blood), Group C (IV collagenase), Group D (non-heparin autologous blood), Group E (control), and Group F (sham). Experiments were performed under a project license (No.: 2019130) granted by the Ethics Committee of the Affiliated Huadu Hospital, Southern Medical University, in compliance with the institutional guideline for the care and use of animals.

\section{Constructing the animal model of brain edema}

First, the skull was needled by micro injector into the caudate nucleus: Group A, $10 \mu \mathrm{L} \mathrm{IV}$ collagenase $+30 \mu \mathrm{L}$ Heparin autologous blood $+30 \mu \mathrm{L}$ non-heparin autologous blood; Group B, $60 \mu \mathrm{L}$ heparin autologous blood; Group C, $10 \mu \mathrm{L}$ IV collagenase; Group D, $60 \mu \mathrm{L}$ Non heparin autologous blood; Group E, not processed; and Group F, $60 \mu \mathrm{L}$ normal saline. Second, the skin was cut with the center of the needle point in groups A, B, C, and D. A bone window was opened to $8 \mathrm{~mm}$, and a liquid nitrogen freezer probe $\left(-196^{\circ} \mathrm{C}\right.$, diameter $5 \mathrm{~mm}$, Sigma-Aldrich, St Louis, MO, USA) was placed on the surface of the dura mater for $30 \mathrm{~s}$. Then, the incision was sutured. Third, neurological deficits were scored according to the Longa/Bederson scales the next day.

\section{Measurement of brain tissue water content, $\mathrm{K}^{+}, \mathrm{Na}^{+}, \mathrm{Ca}^{2+}$}

A total of 20 rats were sacrificed in each group at 4 days. Of the 20, the wet weight of 10 of the rat brains were recorded by electronic scales, weighed again after drying for $48 \mathrm{~h}$, and the Billiot formula was used to calculate water content. Drying brain tissue was put into $1 \mathrm{~mL}$ concentrated nitric acid to digest for a week, and then atomic absorption spectroscopy (HI7600-020, Shimadzu, Kyoto, Japan) was used to determine the content of $\mathrm{K}^{+}, \mathrm{Na}^{+}$, and $\mathrm{Ca}^{2+}$.

\section{Glial cell culture and identification}

The rest of the rats in each group were sacrificed, and 
$100 \mathrm{mg}$ of perihematoma brain tissue was removed. The tissue was placed in double antibody $(100 \mathrm{U} / \mathrm{mL}$ penicillin + $100 \mu \mathrm{g} / \mathrm{mL}$ streptomycin) Roswell Park Memorial Institute (RPMI)-1640 nutrient Fluid with $0.1 \%$ trypsin to digest at $37^{\circ} \mathrm{C}$ for $30 \mathrm{~min}$, and was then filtered by 200 mesh. The liquid level junction cloudy gray layer was absorbed, and the final concentration of $1 \times 10^{5} / \mathrm{mL}$ cells were inoculated into the culture flask.

Mouse anti-human keratin 18 (1:150) was added to the cells after climbing the slices with fluorescein isothiocyanate (FITC), and then mouse anti-human vimentin (1:150) Cy3 labeled was added, followed by washing in phosphatebuffered saline (PBS) liquid 3 times for $3 \mathrm{~min}$. The cells were then sealed in buffered glycerol, and light and laser scanning confocal microscopes were used for observation and identification.

\section{Apoptosis of glial cells by flow cytometry assay}

The culture was adjusted to a $[6-10] \times 10^{4} / \mathrm{mL}$ single cell suspension, inoculated in medium culture dishes with $2 \%$ trypsin digestion. The following were added in proper order: $1 \times$ binding buffer, annexin V-FITC, and propidium iodide, after mixing, room temperature avoidance reaction was undertaken for $15 \mathrm{~min}$, and was followed by flow cytometry detection.

\section{Apoptosis of glial cells by TUNEL assay}

The cells were inoculated at a concentration of $4 \times 10^{4} / \mathrm{mL}$ in 12 well plates; after $24 \mathrm{~h}$, the culture was replaced with serum free RPMI-1640 medium, and the right amount of 4',6-diamino-2-phenylindole (DAPI) was added. A terminal deoxynucleotidyl transferase (TdT) buffer solution was incubated at room temperature for $5 \mathrm{~min}$; followed by 3,3'-diaminobenzidine (DAB) developing. The cells were observed under the fluorescent microscope after mounting, at an excitation wavelength of $360 \mathrm{~nm}$ and emission wavelength of $460 \mathrm{~nm}$.

\section{Proliferation of glial cells by CCK- 8 assay}

The cells were transfected for $48 \mathrm{~h}$, followed by routine culture of Dulbecco's Modified Eagle Medium (DMEM) containing $10 \%$ fetal bovine serum (FBS). They were then inoculated in 96 well plates, adjusted to the cell concentration to [1-2] $\times 10^{3}$ cells/well, cultured for $48 \mathrm{~h}$ after post wall, and added to the CCK- $810 \mu \mathrm{L}$ reagent. The cells were subjected to oscillation after incubation for $4 \mathrm{~h}$ at room temperature. The absorbance value $(450 \mathrm{~nm})$ of each well was measured on the enzyme immunoassay instrument.

\section{Proliferation of glial cells by EdU assay}

Taken the logarithmic growth phase of cell per well, $5 \times 10^{4}-$ $1 \times 10^{5}$ cells were seeded in 96 well plates. After 30 min of incubation, $2 \mathrm{mg} / \mathrm{mL}$ of $4 \%$ glycine was added for $5 \mathrm{~min}$. Next, a concentration of $2 \mathrm{mg} / \mathrm{mL}$ of glycocoll was added for $5 \mathrm{~min}$, followed by hatching in $4 \%$ paraformaldehyde for $30 \mathrm{~min}$. Finally, the cells were immersed in $1 \times$ Apollo $^{\circledR}$ staining reaction solution, and were the observed under the fluorescent microscope.

\section{Migration of glial cell by scratch test assay}

The cell suspension was added into 6 well plates, and adherents were used to create a monolayer cell, and 4 horizontal lines were uniformly drawn using a disinfected $20 \mu \mathrm{L}$ needle head. The cells were then washed 3 times in PBS, and added to a culture medium containing no blood, and $5 \% \mathrm{CO}_{2}$ incubator cultured at $37{ }^{\circ} \mathrm{C}$. Pictures were taken under the microscope at 0,24 , and $48 \mathrm{~h}$, and the width of scratches were measured and recorded.

\section{Invasion of glial cell by transwell assay}

The cells were placed onto fiber poly carbonate of the transwell upper chamber, $70 \%$ ethanol was used to fix the cells, and $500 \mu \mathrm{L}$ of $0.1 \%$ crystal violet was added to 24 well plates, Random selection of 4 fields of view per well were observed under the inverted microscope, and the mean value of the cell number in the lower chamber of the transwell was calculated as the number of invasive cells. The measurement was recorded and a picture was taken.

\section{MMP-9 and AQP4 mRNA of glial cell by RT-PCR assay}

The cells were added to $0.3 \mathrm{~mL}$ chloroform, and centrifuged at $4^{\circ} \mathrm{C}, 13,000 \mathrm{rpm}$ for $15 \mathrm{~min}$. The supernatant was discarded, and 30-50 DEPC was added to solution RNA after oscillation. They were then placed in the PCR instrument, and $\beta$-actin and target genes were also simultaneously amplified. The results of the accumulation of fluorescence were quantified by TaqMan probe (Hieff Unicon ${ }^{\circledR}$ qPCR TaqMan Probe Master Mix \#11205ES08).

The design results of the primers are shown in Table 1. 
Table 1 Gene sequences of primers

\begin{tabular}{llcc}
\hline Gene name & \multicolumn{1}{c}{ Primer sequence $\left(5^{\prime}-3^{\prime}\right)$} & Annealing temperature $\left({ }^{\circ} \mathrm{C}\right)$ & Product length $(\mathrm{bp})$ \\
\hline$\beta$-actin & F: CCTGTACGCCAACACAGTGC; R: ATACTCCTGCTTGCTGATCC & 57 & 211 \\
MMP-9 & F: CCTGAAGCTGACCCAGGTAG; R: TTCCAAACTGCATCAATGAAT & 58 & 133 \\
AQP4 & F: CATGAAGCTGAGACAGGGCA; R: GCCCAAACTGCTCAAATGCAC & 63 & 109 \\
\hline
\end{tabular}

F, upstream primer sequence; R, downstream; MMP-9, matrix metalloproteinase-9; AQP4, aquaporin-4.
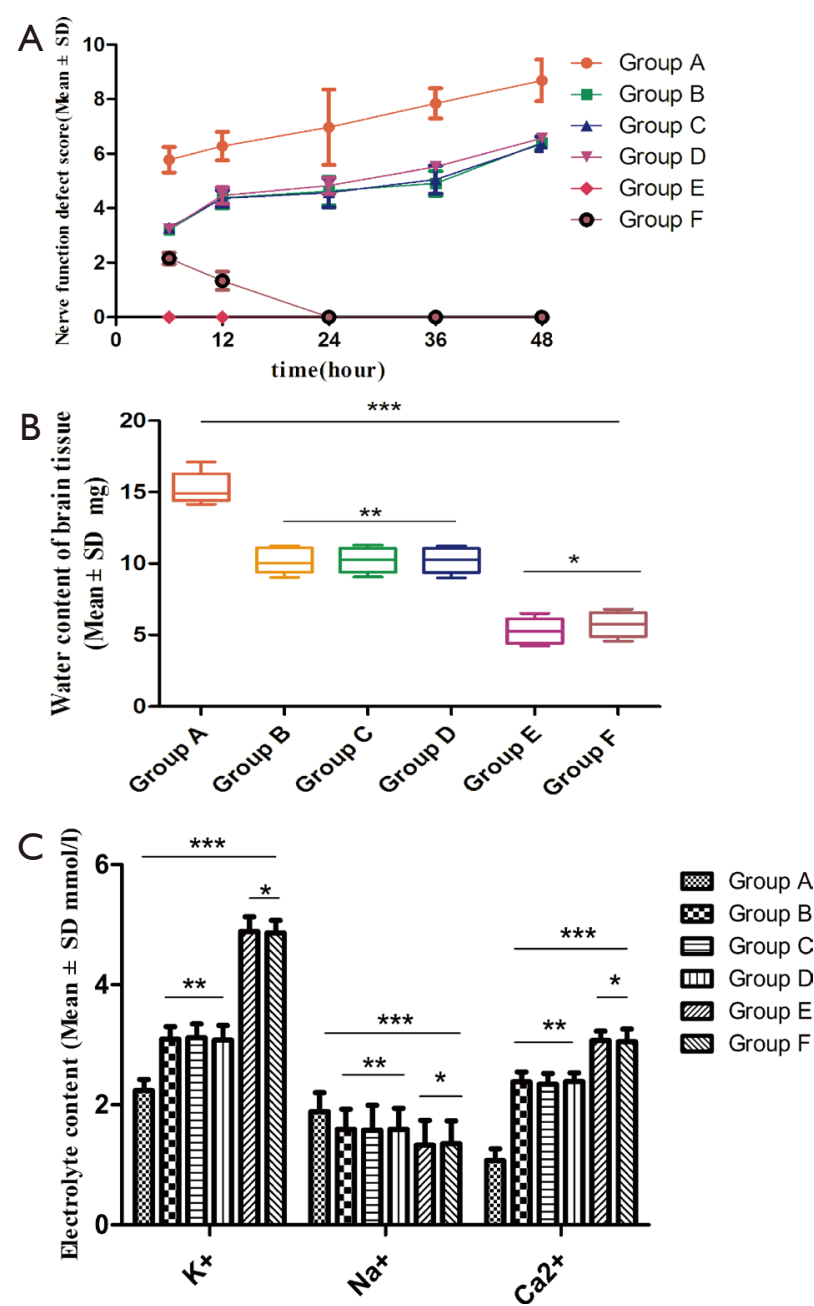

Figure 1 Results of external neurological deficit and brain water content. The ns between groups was not significant, there was no significant difference. ${ }^{* * *} \mathrm{P}<0.05$, the difference was statistically significant. Data represent mean \pm SD from three independent experiments using one-way ANOVA analyses and two-tailed Student's $t$-test. (A) Longa/berderson score of neurological deficits, Group A was the most significant, $\mathrm{P}<0.05$. (B) Water content, Group A was the most significant, ${ }^{*} \mathrm{P}>0.05 ;{ }^{* *} \mathrm{P}>0.05 ;{ }^{* * *} \mathrm{P}<0.05$. (C) Comparison of electrolyte $\mathrm{K}^{+}, \mathrm{Na}^{+}, \mathrm{Ca}^{2+}$, Group A was the most significant, ${ }^{*} \mathrm{P}>0.05 ;{ }^{* *} \mathrm{P}>0.05 ;{ }^{* *} \mathrm{P}<0.05$.
MMP-9 and AQP4 protein of glial cell by western blot assay

The protein lysis solution was added on the ice after the cells had been transfected for 48-72 h. Following sodium dodecyl sulphate-polyacrylamide gel electrophoresis (SDSPAGE), polyvinylidene difluoride (PVDF) was transferred film on the ice and closed. They were then incubated overnight in an anti-dilution solution $(1: 1,000)$ at $4{ }^{\circ} \mathrm{C}$. After washing in tris buffered saline and tween 20 (TBST) a second antibody was added and incubated for 1.5 hours at room temperature, followed by the addition of a developing reagent. The results were detected using a gel imaging instrument (Bio-Rad, Hercules, CA, USA).

\section{Statistical analysis}

The statistical software SPSS 22.0 (SPSS Inc., IBM Corp., Chicago, IL, USA) was used for all statistical analysis. Measurement data were expressed as mean \pm standard deviation $(\bar{x} \pm \mathrm{s})$, Methods using single factor analysis of variance and least significant difference (LSD) $t$-test; a $\mathrm{P}$ value $<0.05$ was considered to be statistically significant.

\section{Results}

\section{Effect of external nerve function defect and brain water content in $S D$ rats}

The Longa/Berderson scores were significantly different in each group, and the differences were statistically significant $(\mathrm{P}<0.05)$; when comparing Groups $\mathrm{B}, \mathrm{C}$, and $\mathrm{D}$, the differences were not significant $(\mathrm{P}>0.05)$; the groups $\mathrm{E}$ and F were significantly different $(\mathrm{P}<0.05)$ at the time points of 6 and $12 \mathrm{~h}$, however the differences were not significant at the 24, 36, and $48 \mathrm{~h}$ intervals $(\mathrm{P}>0.05)$ (Figure $1 A)$. Brain tissue water content, and electrolyte $\mathrm{K}^{+}, \mathrm{Na}^{+}$, and $\mathrm{Ca}^{2+}$ content in each group were determined (Figure 1B,C). 

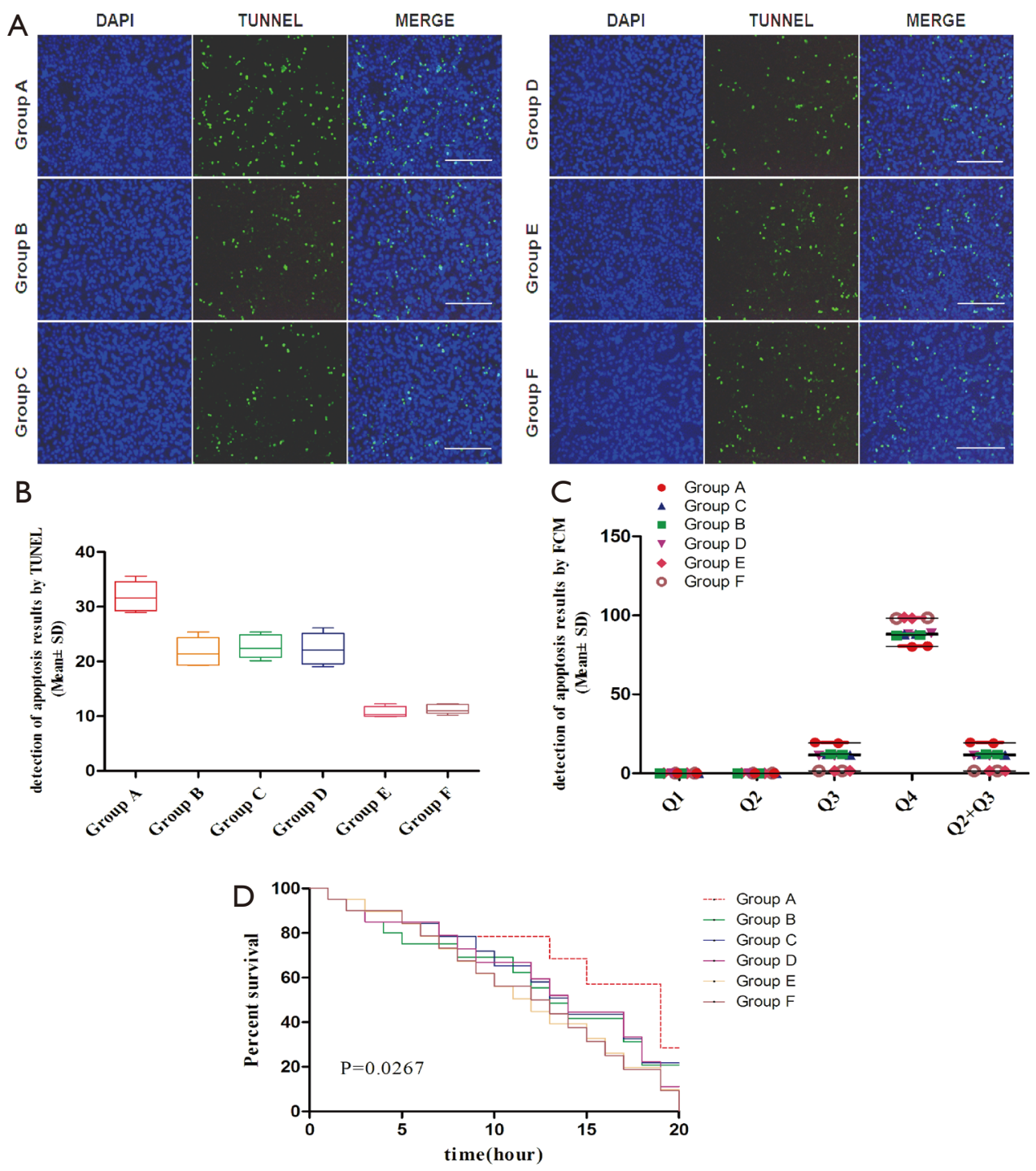

Figure 2 Apoptosis of glial cells by FCM and TUNEL assay and survival curve result. The ns between groups was not significant, there was no significant difference. $\mathrm{P}<0.05$, the difference was significant, it's statistically significant. Data represent mean \pm SD from three independent experiments using one-way ANOVA analyses and two-tailed Student's $t$-test. (A,B) TUNEL measurement of apoptosis of glial cells, Group A was the most significant, $\mathrm{P}<0.05$; E: comparison of the number of glial cell apoptosis, Group A was the most significant, $\mathrm{P}<0.05$ (peroxidase DAB staining; scale bars $=50 \mu \mathrm{m}$ ). (C) FCM test for apoptosis of glial cells, as group A, the following sequence alignment, Group A was the most significant, $\mathrm{P}<0.05$. Q4 as the survival of glial cells, Q2 and Q3 as the early apoptosis and late apoptosis of glial cells, apoptosis of group A was the most significant, $\mathrm{P}<0.05$. (D) The survival curve of apoptosis in each group, limit to 20 h. FCM, flow cytometry technique.

\section{Apoptosis and proliferation of glial cells in SD rat groups}

Comparison of apoptosis and survival curves of FCM and TUNEL was performed in each group; the difference of group A was the most significant, and it was statistically significant $(\mathrm{P}<0.05)$; Groups $\mathrm{B}, \mathrm{C}$, and $\mathrm{D}$ were comparative among the groups, and groups $\mathrm{E}$ and $\mathrm{F}$ were comparable among groups; the differences were not significant $(\mathrm{P}>0.05)$ (Figure 2).

Comparison of glial cell proliferation of CCK-8 and EdU in each group, Group A was the most significant $(\mathrm{P}<0.05)$. According to the EdU measurement of proliferation, group A was least proliferative (Figure $3 A, B$ ), the CCK-8 

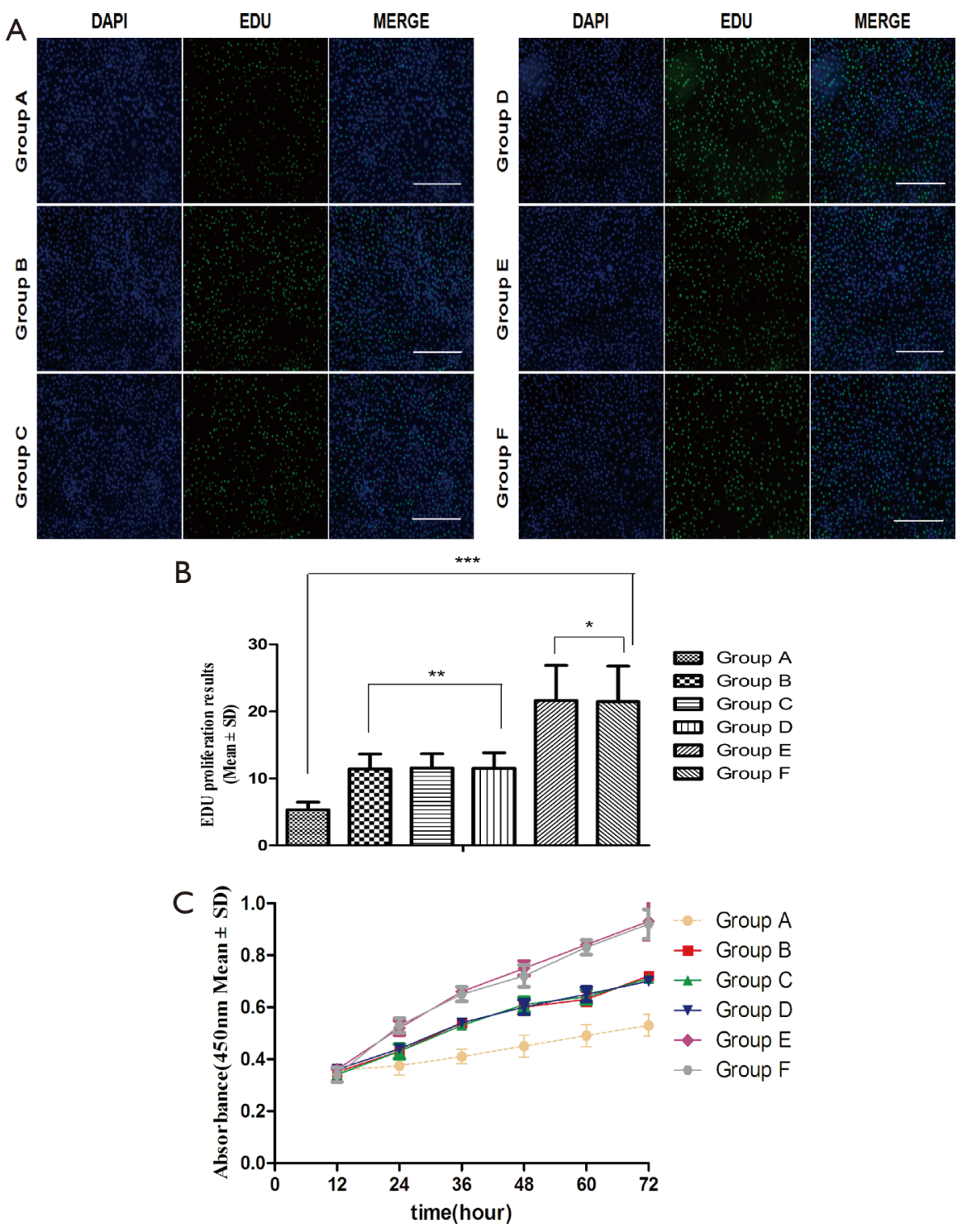

Figure 3 Glial cell proliferation by CCK-8 and EDU assay result. The ns between groups was not significant, there was no significant difference. ${ }^{* * *} \mathrm{P}<0.05$, the difference was significant, it's statistically significant. Data represent mean $\pm \mathrm{SD}$ from three independent experiments using one-way ANOVA analyses and two-tailed Student's $t$-test. (A) The proliferation of glial cells by EDU assay (immunofluorescence staining, $\times 200$ ). DAPI, blue nuclear count; EDU, green positive cell count, MERGE synthesis map statistics EDU positive cell ratio (green cell positive count/blue nuclear count), group A difference was the most significant, $\mathrm{P}<0.05$ (scale bars $=50 \mu \mathrm{m}$ ). (B) Comparison of the number of proliferation of glial cells by EDU assay, Group A was the least, ${ }^{*} \mathrm{P}>0.05$; ${ }^{* *} \mathrm{P}>0.05$; ${ }^{* * *} \mathrm{P}<0.05$. $(\mathrm{C}) \mathrm{Ability}$ of glial cells proliferation by CCK- 8 assay, $12 \mathrm{~h}$ for the interval, the proliferation of group A was the least, the difference was the most significant, ${ }^{*} \mathrm{P}>0.05 ;{ }^{* *} \mathrm{P}>0.05 ;{ }^{* * *} \mathrm{P}<0.05$. 

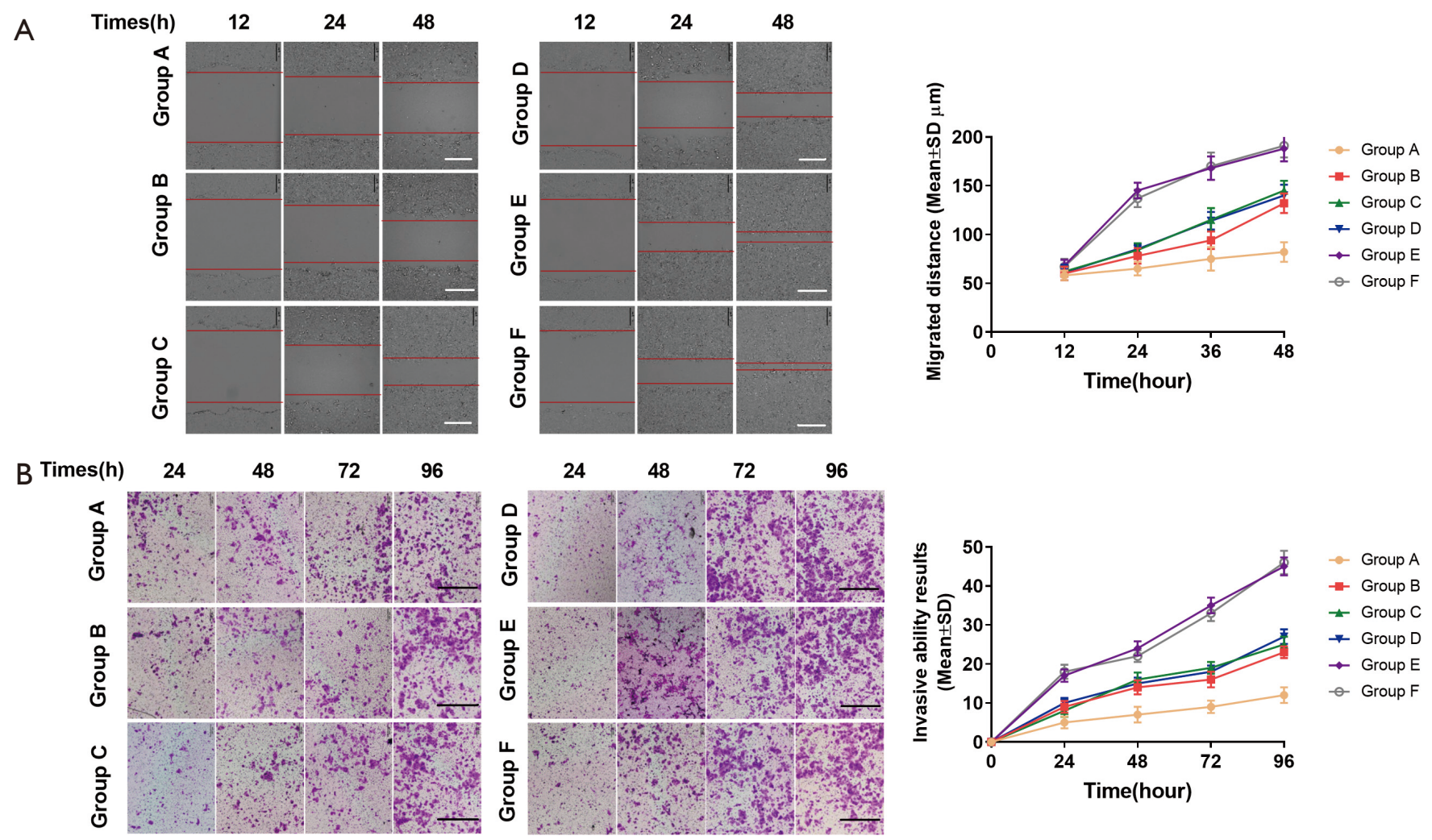

Figure 4 Glial cell migration and invasion result by scratch test and transwell assay. The ns between groups was not significant, there was no significant difference. $\mathrm{P}<0.05$, the difference was significant, it's statistically significant. Data represent mean \pm SD from three independent experiments using one-way ANOVA analyses and two-tailed Student's $t$-test. (A) Migration distance comparison, Group A was the most significant, $\mathrm{P}<0.05$. Glial cell migration by scratch test assay, $12 \mathrm{~h}$ as interval, Group A was the most significant, $\mathrm{P}<0.05$ (scale bars $=20 \mu \mathrm{m}$ ). (B) Glial cell invasion by transwell assay, $24 \mathrm{~h}$ as interval, Group A was the most significant, $\mathrm{P}<0.05$. Comparison of invasive ability, Group A was the most significant, $\mathrm{P}<0.05$ (crystal violet staining; scale bars $=50 \mu \mathrm{m}$ ).

measurement of proliferation, the absorbance of group A was the lowest (Figure 3C).

\section{Migration and invasion of glial cells in SD rat groups}

Comparison of cell migration and invasion results of the scratch and transwell assays in each group, the difference shown by group A was the most significant, and the difference was statistically significant $(\mathrm{P}<0.05)$ (Figure 4).

\section{Results of differences in MMP-9 and AQP4 mRNA of glial cells and proteins in each group}

Differences of AQP4 and MMP-9 mRNA and protein expression in glial cells by Real time-PCR and western blot quantitative detection (Figure 5).

\section{Discussion}

The animal model of intracerebral hemorrhagic brain edema has been widely used to study the etiology and pathology of brain edema in humans (14-16). Brain edema after cerebral hemorrhage could cause extensive edema (11-13), and preventing the occurrence or aggravation of brain edema is an important factor to reduce the mortality and disability rates of cerebral hemorrhage (17). The previous animal models were unable to fully reflect the clinical and pathophysiological manifestations of cerebral hemorrhage brain edema (18-20); therefore, it was very important to establish a compound animal model of cerebral hemorrhage brain edema. The clear signs of brain edema shown by MMP-9 and AQP4 (21-23) meant that MMP-9 and AQP4 could be used to verify the accuracy of the model, and the experimental results were able to be transformed 

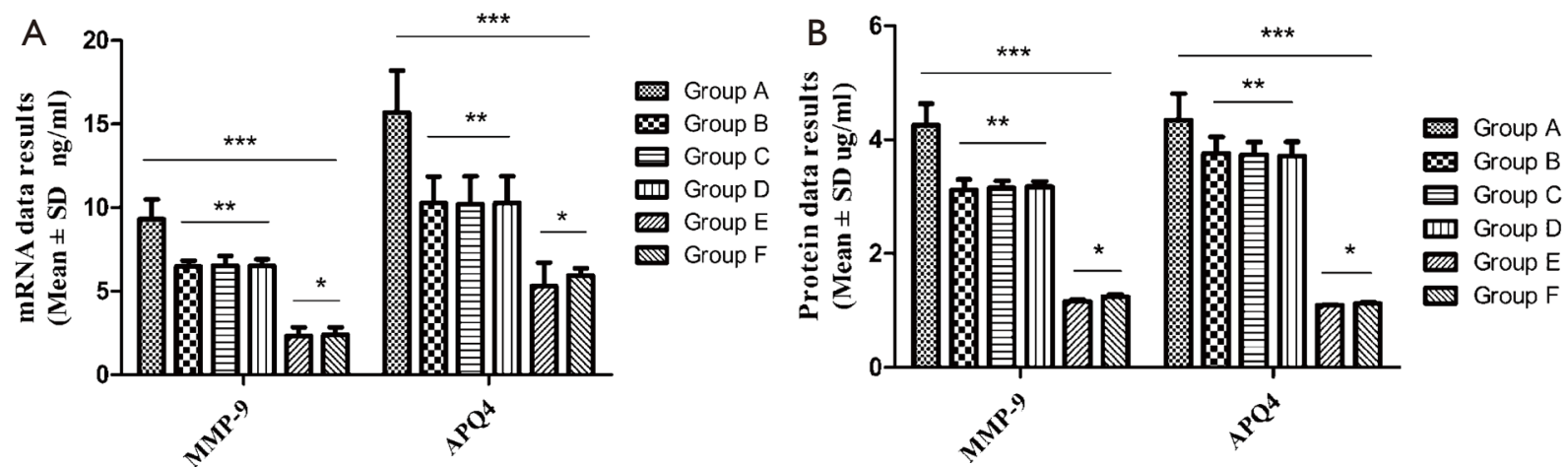

Figure 5 Results of AQP4 and MMP-9 mRNA and protein in glial cells. The ns between groups was not significant, there was no significant difference. ${ }^{* * *} \mathrm{P}<0.05$, the difference was significant, it's statistically significant. Data represent mean $\pm \mathrm{SD}$ from three independent experiments using one-way ANOVA analyses and two-tailed Student's $t$-test. (A) Compared with AQP4 and MMP-9 mRNA, Group A was the most significant, ${ }^{*} \mathrm{P}>0.05 ;{ }^{*} \mathrm{P}>0.05 ;{ }^{* * *} \mathrm{P}<0.05$. (B) Western blot was compared with the results of MMP-9 and AQP4 protein in glial cells, Group A was the most significant. Compared with the MMP-9 and AQP4 protein of glial cells in each group, Group A was the most significant, ${ }^{*} \mathrm{P}>0.05 ;{ }^{* *} \mathrm{P}>0.05$; ${ }^{* *} \mathrm{P}<0.05$.

into clinical setting (24-26). In this study, we had used IV collagenase, non-heparin, and heparin autologous arterial blood to induce the interaction; and combined with epidural target freezing by liquid nitrogen, we successfully established a compound animal model of cerebral hemorrhage brain edema.

The results showed that in group F, the Longa/Bederson score of neurological deficits was present in the $24 \mathrm{~h}$ after injection of normal saline, and we considered that the normal saline had few occupying effects. However, due to the reasons of infiltration, the brain edema was not significant, and was consistent with that of group $\mathrm{E}$ after $24 \mathrm{~h}$. The brain tissue content of $\mathrm{K}^{+}, \mathrm{Na}^{+}$, and $\mathrm{Ca}^{2+}$ changed with the increasing degree of brain edema, and the change was statistically significant. This was consistent with the changes of $\mathrm{K}^{+}, \mathrm{Na}^{+}$, and $\mathrm{Ca}^{2+}$ in the serum of patients with brain edema.

The FCM and TUNEL assays were used to detect the apoptosis of glial cells, and Group A was the most significant $(\mathrm{P}>0.05)$. We considered that as the pace of brain edema gradually increased, apoptotic bodies increased after the apoptosis of glial cells, which were then swallowed by phagocytic cells. In future research, we will focus on the changes of apoptotic bodies and the mechanism of phagocytosis in the glial cells after brain edema. The results of CCK-8 and EdU showed that the proliferative ability of glial cells was obviously decreased after the onset of cerebral edema, Group A was the most significant $(\mathrm{P}>0.05)$, which may have been related to the degeneration of the mitochondria in the glial cells following the onset of cerebral edema. The changes to the migration and invasion of glial cells after brain edema was initiated were revealed by scratch and transwell tests, the migration and invasion abilities of group A were the weakest; Groups B, C, and D occurred in a slow platform in the migration of $24 \mathrm{~h}$, and had rapidly and significantly increased by $36 \mathrm{~h}$; however, group A showed a trend of gradual change. Therefore, the stability of the compound animal model was significantly better than that of the other single model groups.

The results of Real time-PCR and western blot showed that MMP-9 and AQP4 were significantly up-regulated in mRNA and protein; Group A was the most significant $(\mathrm{P}>0.05)$, and groups $\mathrm{E}$ and $\mathrm{F}$ showed low expression. This was consistent with the biological characteristics of clinical human cerebral edema.

Therefore, we considered that the application of brain edema markers MMP-9 and AQP4 was a credible way to confirm the accuracy of the model.

\section{Conclusions}

In summary, the stability and practicability of the compound animal model of brain edema from cerebral hemorrhage, was superior to the single animal model. The compound model is an ideal animal model for the study of brain edema after intracerebral hemorrhage. This study showed that the experimental results are able to be transferred to the clinical setting, allowing more accurate diagnosis and treatment of cerebral hemorrhagic brain edema with positive 
significance.

\section{Acknowledgments}

Thanks to AME for helping with the article language.

We are grateful for the technical support of the Neurosurgery Department of Hua Du Hospital of the Southern Medical University for preparation of the samples. We would like to thank professor Hua Xiao for their help in collecting samples for this study, and Dr. Xiang Ming Jiang for help with organizing the samples.

Funding: This research was funded by grants from the Traditional Chinese Medicine Science and Technology Project of Guangdong Province (20191256), and The Medical Research Foundation of the People's Hospital of Huadu District (2019A05).

\section{Footnote}

Reporting Checklist: The authors have completed the STROBE reporting checklist. Available at http://dx.doi. org/10.21037/apm-20-2308

Data Sharing Statement: Available at http://dx.doi. org/10.21037/apm-20-2308

Conflicts of Interest: Both authors have completed the ICMJE uniform disclosure form (available at http://dx.doi. org/10.21037/apm-20-2308). The authors have no conflicts of interest to declare.

Ethical Statement: The authors are accountable for all aspects of the work in ensuring that questions related to the accuracy or integrity of any part of the work are appropriately investigated and resolved. Experiments were performed under a project license (No.:2019130) granted by the Ethics Committee of the Affiliated Huadu Hospital, Southern Medical University, in compliance with the institutional guideline for the care and use of animals.

Open Access Statement: This is an Open Access article distributed in accordance with the Creative Commons Attribution-NonCommercial-NoDerivs 4.0 International License (CC BY-NC-ND 4.0), which permits the noncommercial replication and distribution of the article with the strict proviso that no changes or edits are made and the original work is properly cited (including links to both the formal publication through the relevant DOI and the license). See: https://creativecommons.org/licenses/by-nc-nd/4.0/.

\section{References}

1. Michinaga S, Nagase M, Matsuyama E, et al. Amelioration of Cold 1. Injury-Induced Cortical Brain Edema Formation by Selective Endothelin ETB Receptor Antagonists in Mice. PLoS One 2014;9:e102009.

2. Kimbler DE, Shields J, Yanasak N, et al. Activation of $\mathrm{P} 2 \mathrm{X} 7$ promotes cerebral edema and neurological injury after traumatic brain injury in mice. PLoS One 2012;7:e41229.

3. Talley Watts L, Sprague S, Zheng W, et al. Purinergic $2 \mathrm{Y} 1$ receptor stimulation decreases cerebral edema and reactive gliosis in a traumatic brain injury model. J Neurotrauma 2013;30:55-66.

4. Wajima D, Nakagawa I, Nakase H, et al. Neuroprotective effect of suppression of astrocytic activation by arundic acid on brain injuries in rats with acute subdural hematomas. Brain Res 2013;1519:127-35.

5. Marmarou CR, Liang X, Abidi NH, et al. Selective vasopressin-1a receptor antagonist prevents brain edema, reduces astrocytic cell swelling and GFAP, V1aR and AQP4 expression after focal traumatic brain injury. Brain Res 2014;1581:89-102.

6. He Z, Wang X, Wu Y, et al. Treadmill pre-training ameliorates brain edema in ischemic stroke via downregulation of aquaporin-4: an MRI study in rats. PLoS One 2014;9:e84602.

7. Deng J, Zhao F, Yu X, et al. Expression of aquaporin 4 and breakdown of the blood-brain barrier after hypoglycemiainduced brain edema in rats. PLoS One 2014;9:e107022.

8. Mao Y, Shen Z, Zhu H, et al. Observation on therapeutic effect of stereotactic soft channel puncture and drainage on hypertensive cerebral hemorrhage. Ann Palliat Med 2020;9:339-45.

9. Katada R, Akdemir G, Asavapanumas N, et al. Greatly improved survival and neuroprotection in aquaporin-4knockout mice following global cerebral ischemia. FASEB J 2014;28:705-14.

10. Krafft PR, McBride DW, Lekic T, et al. Correlation between subacute sensorimotor deficits and brain edema in two mouse models of intracerebral hemorrhage. Behav Brain Res 2014;264:151-60.

11. Krafft PR, Caner B, Klebe D, et al. PHA-543613 preserves blood-brain barrier integrity after intracerebral hemorrhage in mice. Stroke 2013;44:1743-7.

12. Rolland WB, Lekic T, Krafft PR, et al. Fingolimod reduces cerebral lymphocyte infiltration in experimental models of rodent intracerebral hemorrhage. Exp Neurol 
2013;241:45-55.

13. Ma Q, Manaenko A, Khatibi NH, et al. Vascular adhesion protein-1 inhibition provides antiinflammatory protection after an intracerebral hemorrhagic stroke in mice. J Cereb Blood Flow Metab 2011;31:881-93.

14. Zhong Z, Wang B, Dai M, et al. Carvacrol alleviates cerebral edema by modulating AQP4 expression after intracerebral hemorrhage in mice. Neurosci Lett 2013;555:24-9.

15. Li W, Bao G, Chen W, et al. Connexin 43 Hemichannel as a Novel Mediator of Sterile and Infectious Inflammatory Diseases. Sci Rep 2018;8:166.

16. Johnson AM, Roach JP, Hu A, et al. Connexin 43 gap junctions contribute to brain endothelial barrier hyperpermeability in familial cerebral cavernous malformations type III by modulating tight junction structure. FASEB J 2018;32:2615-29.

17. Li Z, Zhang S, Cao L, et al. Tanshinone IIA and Astragaloside IV promote the angiogenesis of mesenchymal stem cell-derived endothelial cell-like cells via upregulation of $\mathrm{Cx} 37, \mathrm{Cx} 40$ and $\mathrm{Cx} 43$. Exp Ther Med 2018;15:1847-54.

18. Ni X, Zhang L, Peng M, et al. Hydrogen Sulfide Attenuates Hypertensive Inflammation via Regulating Connexin Expression in Spontaneously Hypertensive Rats. Med Sci Monit 2018;24:1205-18.

19. Koncsos G, Varga ZV, Baranyai T, et al. Nagarse treatment of cardiac subsarcolemmal and interfibrillar mitochondria leads to artefacts in mitochondrial protein quantification. J Pharmacol Toxicol Methods 2018;91:50-8.

Cite this article as: Zhao XY, Zhang XL. Establishment of composite experimental animal model of brain edema after cerebral hemorrhagic. Ann Palliat Med 2021;10(1):362-371. doi: 10.21037/apm-20-2308
20. Li XF, Zhang XJ, Zhang C, et al. Ulinastatin protects brain against cerebral ischemia/reperfusion injury through inhibiting MMP-9 and alleviating loss of ZO-1 and occludin proteins in mice. Exp Neurol. 2018;302:68-74.

21. Lv Y, Fu L. The potential mechanism for Hydroxysafflor yellow A attenuating blood-brain barrier dysfunction via tight junction signaling pathways excavated by an integrated serial affinity chromatography and shotgun proteomics analysis approach. Neurochem Int 2018;112:38-48.

22. Tang $\mathrm{Y}$, Tong $\mathrm{X}$, Li $\mathrm{Y}$, et al. JAK2/STAT3 pathway is involved in the protective effects of epidermal growth factor receptor activation against cerebral ischemia/ reperfusion injury in rats. Neurosci Lett 2018;662:219-26.

23. Izuhara K, Nunomura S, Nanri Y, et al. Periostin in inflammation and allergy. Cell Mol Life Sci 2017;74:4293-303.

24. Liu L, Kawakita F, Fujimoto M, et al. Role of Periostin in Early Brain Injury After Subarachnoid Hemorrhage in Mice. Stroke 2017;48:1108-11.

25. Ji WJ, Chou XM, Wu GQ, et al. Association between serum periostin concentrations and outcome after acute spontaneous intracerebral hemorrhage. Clin Chim Acta 2017;474:23-7.

26. Dong XQ, Yu WH, Du Q, et al. Serum periostin concentrations and outcomes after severe traumatic brain injury. Clin Chim Acta 2017;471:298-303.

(English Language Editor: J. Jones) 